\title{
ASSESMENT OF THE INDUSTRY COMPETITIVENESS OF THE BALTIC STATES IN THE EU DURING THE PERIOD OF ECONOMIC RECESSION
}

\author{
Rita REMEIKIENE, Grazina STARTIENE, Daiva DUMCIUVIENE \\ Department of Economics, Kaunas University of Technology, \\ Laisves al. 55, Kaunas, Lithuania
}

Received 04 August 2014; accepted 25 November 2014

\begin{abstract}
The purpose of the article is to carry out the assessment of the industrial competitiveness of the Baltic States in the EU during the period of economic recession. Revealed comparative advantage (RCA) and Symmetric index (SI) index values revealed that after the period of economic recession, the growth of the industrial competitiveness of the Baltic States, considering it from export positions, is slower in comparison with GDP changes. Latvia has taken strong competitive positions in the industry of raw materials; Estonia also has medium comparative advantage in the industry of raw materials, while Lithuania has the comparative advantage in the industries of mineral fuels, lubricants and related materials. Export competitiveness index (XCI) results showed that all three Baltic States had growing competitive advantage in the industries of food, drinks and tobacco during both the period of economic recession and the period of economic revival. In the period of economic revival Estonia showed the growth potential in the industries of chemicals and related products, while Lithuania - in the industry of raw materials and related products. The identification of competitive industries during the periods of economic recession and revival can provide the governments of the Baltic States with the target data not only for supporting export companies, but also for taking the best decisions to improve the business environment in the industries that have the competitive advantage.
\end{abstract}

Keywords: industry, industry competitiveness, revealed comparative advantage, Baltic States, economic recession, export.

JEL Classification: F1, F6.

Corresponding author Rita Remeikiene

E-mail: rita.remeikiene@ktu.lt 


\section{Introduction}

The levels of economic openness and integration of the Baltic States determine the necessity of broader analysis of the competitiveness of these States in the EU or the global markets. Although the recent development of the service sector still remains intensive (with reference to the data of Eurostat, services in the percentage of total employment in Estonia reached 65.6, in Latvia - 68.3 and in Lithuania - 66.1 in 2012), industry has not lost its role as the basis of the total economy of the country. With reference to the statistical data of Eurostat, the gross value added generated in the industrial sectors in Estonia and Latvia grew in comparison to the pre-crisis and recession periods. The GDP, generated by the industrial sector, reached 20.3 per cent in 2007 and 23.1 per cent in 2010 in Estonia, and respectively 14.3 per cent and 16.7 per cent in Latvia. In Lithuania, this rate remained unchanged and amounted to 22.1 per cent. The results of the study (Fadejeva, Melihovs 2008) show that the Baltic economies are similar in economic development. Although the Baltic States are similar in terms of their geographical position, cultural, political and economic development (Fadejeva, Melihovs 2008), the Global Competitiveness Index (2014) (GCI) during the period of 2013-2014 shows different competitiveness positions: $\mathrm{GCI}_{\text {Estonia }}-32^{\text {nd }}$ place with 4.65 points among 148 countries, $\mathrm{GCI}_{\text {Lihuania }}-48^{\text {th }}$ place (4.41 points), $\mathrm{GCI}_{\text {Latvia }}-52^{\text {nd }}$ place (4.40 points).

According to Ben,kovskis (2012), the definition of the competitiveness is so broad that it includes an extremely large set of macroeconomic and microeconomic issues. The authors of the article do not aim at the comprehensive analysis of the concept of competitiveness, but apply proposed methods of competitiveness for the assessment of the industry competitiveness of the Baltic States.

Assessment of the competitiveness of different industries is necessary due to several reasons: firstly, it can help to increase general competitiveness of the country, provided the corresponding measures are applied; secondly, it can help focus on the export from the most competitive industries with the goal to increase the industry competitiveness in foreign markets. Governments try to stimulate the sales of goods to export and extend their business abroad (Razavi et al. 2012). Moreover, in accordance with the update of the long-term strategy of the development of Lithuanian economy by 2015, it is recommended to perform the studies of industry competitiveness annually. The analysis of the scientific literature has enabled the detection of the main methodologies for competiveness assessment. The competitiveness of different EU and other countries' industries in the EU or global markets is assessed using such indexes methods: industry competitiveness index (ICI) (Fischer, Schornberg 2007); trade-intensity index; revealed comparative (symmetric) advantage (RCA); specialization in production using the Hummel and Klenow intensive margins index (HKIM); Grubel-Lloyd index (GL); Constant-Market-Shares (CMS) analysis of export growth; Kreinin-Finger similarity index; intra-industry trade analysis (Fortunas et al. 2007; Haar 2010; Mahmood 2010; Nilsson et al. 2007; Taylor 2009; Vasta 2010; Vogiatzoglou 2012; Balasubramanyam, Wei 2005; Oelgemöller 2013; Lederman et al. 2008 and etc.); analysis by the means of multivariate statistical methods (Michalek et al. 2012). 
Although the economic recession had negative impact on all three Baltic States, it is considered to be over, and there is a lack of the scientific research on the effects of the recession on the industries and the competitiveness of the Baltic States. The question arises whether the changing stages of business cycle cause the changes in export structure and the competitiveness of industries. The purpose of the article is the assessment of the industry competitiveness of the Baltic States during the period of economic recession. The following objectives have been set to achieve the purpose stated above: 1) to carry out the analysis of the research results on the assessment of the competitiveness of the industrial sector of the Baltic States; 2) to present the methodology of the empirical research; 3 ) to assess industry competitiveness of the Baltic States using the indexes of revealed comparative advantage, revealed comparative (symmetric) advantage and export competitiveness. The methods of the research include the systemic analysis and synthesis of the scientific literature as well as the analysis of statistical data and mathematical calculations.

The structure of the article is as follows: after this introduction, the results of the research on the industry competitiveness of the Baltic States have been reviewed; the methodology of the research has been presented in the third section; the fourth section is designed for the specification of the results of the empirical research; conclusions have been presented at the end of the article.

\section{The analysis of the research results on the industry competitiveness of the Baltic States}

Economic situation, the volumes of foreign trade, the general level of competitiveness and other aspects of the economy of the Baltic States are the areas often researched by scientists (Dudzevičiūte et al. 2014). Although the Baltic States regained their independence more than 20 years ago, some scientists (Kilduff, Chi 2007; Zaghini 2005) are inclined to call them former Soviet Union countries or former Communist Bloc. Only a few studies include the comparative research of the industry competitiveness of the Baltic States. These studies can be classified into two groups:

- the studies, which include the research of the competitiveness of different industries in the Baltic States in respect of the export: the competitiveness of textile industry according to the RCA and SI indexes (Kilduff, Chi 2007);

- the studies, which include the research of the similarity of the Baltic countries' export to the EU according to the similarity index for the Baltic countries export to the EU (Kaitila 1999); cross-industrial trade specialization between the Baltic States and the EU according to Grubbell-Lloyd and the RCA indexes (Bernatonyte, Normantiene 2009); industrial competitiveness of the Baltic States in the EU market according to the RCA index (Saboniene 2009; Zaghini 2005; Kaitila 2001; Fertő 2007; Misztal 2009); the assessment of the determinants of economic competitiveness in the Baltic States (Buracas et al. 2012).

The summarized results of the scientific research by different authors are presented in Table 1. 
Table 1. Summary of the research results on the industry competitiveness of the Baltic States

\begin{tabular}{llll}
\hline Author, year & Period & $\begin{array}{l}\text { Index/Market } \\
\text { compared }\end{array}$ & \multicolumn{1}{c}{ Result } \\
\hline Kaitila 2001 & $1993-1998$ & $\begin{array}{l}\text { RCA/EU } \\
\text { market }\end{array}$ & $\begin{array}{l}\text { The most dynamic economies (from the three Baltic } \\
\text { States, Estonia got on the list) have significantly } \\
\text { increased the comparative advantage with respect } \\
\text { to the EU with products of high and medium-high } \\
\text { intensity in skilled work. }\end{array}$ \\
\hline
\end{tabular}

$\begin{array}{llll}\text { Zaghini } 2005 & 1993-1994 ; & \text { RCA, Lafay } \\ \text { index/Global } & & \begin{array}{l}\text { For the Baltic countries, an important role in } \\ \text { specialization pattern is still played by wood and its } \\ \text { derivatives, also by many manufactured goods. The } \\ \text { Baltic countries are still largely relying on natural } \\ \text { resources. }\end{array}\end{array}$

Fertö 2007 1993-2003 RCA/Global Comparative advantages in the Baltic countries are still largely based on natural resources (sector 21 , i.e. leather, cork, wood, lime, precious stones, pig iron, copper, aluminium, lead, etc.). The increasing trade specialization focuses mainly on primary and natural resources intensive products. The Baltic States seem to be less successful in the catch up process with the EU compared to the Czech Republic, Hungary, Poland, Slovenia and Slovakia.

\begin{tabular}{|c|c|c|c|}
\hline Misztal 2009 & 1996-2006 & RCA/Global & $\begin{array}{l}\text { Gradual growth of competitiveness is established in } \\
\text { such industries as food and live animals (Lithuania), } \\
\text { different manufactured goods (Lithuania and } \\
\text { Estonia), non-food raw materials except fuel (all } \\
\text { three countries), and manufactured goods classified } \\
\text { by materials (Latvia). Other industries do not } \\
\text { have any or have very little revealed comparative } \\
\text { advantage. }\end{array}$ \\
\hline
\end{tabular}

Saboniene $\quad 2001-2007 \quad$ RCA/Global
2009

Calculations showed that export specialization in the Baltic States was strong in the groups of livestock and products of animal origin. In the group of wood and wooden products, Latvia and Estonia showed better results, the third place was taken by Lithuania. Latvia and Lithuania took strong positions in the group of textile export, Lithuania and Estonia - in the group of different manufactured goods.

\begin{tabular}{lll}
\hline $\begin{array}{l}\text { Bernatonyte, 2001-2007 } \\
\text { Normantiene }\end{array} 2009$ & $\begin{array}{l}\text { RCA, Grubel- } \\
\text { Lloyd index/ } \\
\text { EU market }\end{array}$ & $\begin{array}{l}\text { It was established that the Baltic States had } \\
\text { comparative advantage trading with the EU in food, } \\
\text { drinks, tobacco, raw materials, mineral fuel and } \\
\text { other manufactured goods. The Baltic States did not } \\
\text { have the comparative advantage trading with the EU } \\
\text { in machinery, transport equipment and chemicals. } \\
\text { Analysing trade changes between the Baltic States } \\
\text { and the EU by different industries, it was established } \\
\text { that the indexes of trading in food, drinks, tobacco, } \\
\text { raw materials, mineral fuel and other manufactured } \\
\text { goods increased in } 2007 \text { compared to } 2001 .\end{array}$ \\
&
\end{tabular}


Comparison of the research results is rather difficult due to different classification of the exported goods. In statistical databases, exported goods can be classified according to the Standard International Trade Classifier (SITC), the combined nomenclature (NACE rev. 2, 4, 8), the classification by broad economic categories (BEC), and the classification of products by activity (CPA) so that scientists base their research on the classifier, which best corresponds to the aim of the research. The information summarized in Table 1 shows that the industrial competitiveness of the Baltic States was analysed until their entry to the EU and three years after the entry. Thus, it may be concluded that the Baltic States had the comparative advantage in the EU and the global markets making products from natural resources, i.e. wood, copper, aluminium, lime, leather, cork and others. Since the entry to the EU, the Baltic States increased their competitiveness in food, tobacco, mineral fuel, raw materials and related industries.

As it may be noticed from the analysis of the scientific literature, the changes of the industrial competitiveness of the Baltic States with regard to the EU countries during the periods of economic recession (2008-2009) and economic revival (2010-2012) still remain hardly researched, and there is no any certain data showing whether the level of competitiveness of the dominating industries has remained similar.

\section{Research methodology}

Assessment of competitiveness is economically important due to several reasons: firstly, it is a process enabling to identify the advantages and disadvantages of the economies of the countries seeking a well-balanced and sustainable economic development; secondly, the assessment of competitiveness establishes the background for the creation of effective stimulation measures for the participants of the economy because it identifies the competitive advantages formed by the specificity of goods, services or activities and enables to forecast the ability (or lack thereof) of the industries to cope with the competitive pressure (Malakauskaite, Navickas 2011: 56). The results of the study (Rasiah, Myint 2013) show that foreign firms with the production connected to global value chains enjoy higher export intensity than the national firms even when controlled for age. Scientific literature contains different methodologies for the assessment of general industrial competitiveness, namely the complex assessment of the whole industry of a country, cluster analysis and others (Iammarino, McCann 2006; Meiliene, Snieska 2010; Bair, Gereffi 2001; Newlands 2003 and others). Assessing industrial competitive advantage in international markets, scientists (Vanitha et al. 2013; Vasta 2010; Fortunas et al. 2007; Hinloopen, Marrewijk 2008; Haar 2010 and etc.) emphasize the importance of taking into consideration the foreign trade results.

In European and OECD countries, one of the most widely used methods to assess industrial results is the estimation of export specialization. It can be estimated using RCA index, which helps to assess what product groups take the most important place in the export structure and identifies the groups the most successfully competing in both international and local markets (Saboniene, Pukeliene 2004). According to Shafaei (2009), RCA may be used as an effective tool for measuring the competitiveness of industries. 
The purpose of the article is to identify in what industrial sectors the Baltic States had competitive advantage and how this advantage changed during the period of 2007-2012, i.e. to assess what competitive advantage the Baltic States had in different groups of industrial products during the pre-crisis period, and how this advantage changed during the periods of economic recession and revival. Calculations were performed applying Standard international trade classification (SITC) used for external trade statistics (export and import values and volumes of goods), allowing international comparisons of commodities and manufactured goods. The research was processed in three stages. In the first stage, RCA (Revealed comparative advantage) index was calculated. The RCA index of a given country (country $i$ ) in the export of product (product $j$ ) is defined as follows (Athukorala 2006):

$$
R C A_{j}^{i}=\left(X_{j}^{i} / X_{j}^{w}\right)^{t} /\left(X_{t}^{i} / X_{t}^{w}\right),
$$

where: $X_{j}^{i}$ is the value of country $i$ 's exports of commodity $j ; X_{j}^{w}$ is world exports of commodity $j ; X_{t}^{i}$ is total exports of all goods from country $i$ and $X_{t}^{w}$ is world exports of all goods. Athukorala (2006) noted: "If the value of RCA index exceeds unity for commodity $j$, the country is said to have revealed comparative advantage in the world trade of that commodity. In contrast, if the RCA index is below unity, the country is at a comparative disadvantage in the world trade of the commodity" (Athukorala 2006: 188).

In this research, the formula has been adapted for the assessment of the industrial competitiveness of the Baltic States in the EU market.

For the interpretation of the values of RCA index, the classification of RCA index values presented by Hinloopen, van Marrewijk (2001) was applied. In this classification, class $a$ : RCA values vary in the interval from 0 to 1 ; class $b$ : RCA values vary in the interval from 1 to 2 ; class $c$ : RCA values vary in the interval from 2 to 4 ; class $d$ : RCA values are greater than 4 . Class $a$ includes all commodities or industries/sectors by which a country has not revealed comparative advantage. In other three classes $(b, c, d)$, commodities or industries/ sectors related to the revealed comparative advantage are approximately divided into three levels: "weak comparative advantage" - class $b$, "medium comparative advantage" - class $c$, and "strong comparative advantage" - class $d$. The selection of this classification was determined by the problem of asymmetry typical of the RCA index. It was discussed by Kuldilok et al. (2013) in their research.

In order to avoid the problem of asymmetry, the second stage of the research was designed for the calculation of "Symmetric" Revealed Comparative Advantage Index (further in the text - SI) (Sanidas, Shin 2010):

$$
S I_{i j}=\frac{R C A-1}{R C A+1}
$$

$S I_{i j}$ values vary in the interval from -1 to +1 .

In the third stage of the research XCI was calculated with the purpose of establishing whether an industry had an increasing competitive advantage comparing the period under review with the previous period (Amir 2000). Export competitiveness of country $i$ in the 
export of the selected product $a\left(X C I_{i}^{A}\right)$ is expressed as a ratio of world market share of country $i$ in export of selected product $a$ in period $t$ (the period under review) to its world market share in the previous period:

$$
X \operatorname{XI}_{i}^{A}=\frac{\left(x_{i}^{A} / x_{i}^{w}\right)^{t}}{\left(X_{i}^{A} / X_{i}^{w}\right)^{t-1}},
$$

where: $x_{i}^{A}$ - country $A$ exports of product $i ; X^{A}-$ total exports of country $A ; x_{i}^{w}$ - world exports of product $i$; $X^{w}$ - total world exports; $t$ - the period under review; $t-1$ - the previous period.

According to Amir (2000), if XCI of a product takes the value greater than 1, this points towards rising export competitiveness. The value less than 1 implies declining market share in world markets.

In the research, the formula has been adapted for the assessment of industry competitiveness of the Baltic States in the EU market.

\section{The results of the research on the industry competitiveness of the Baltic States}

Changes of GDP is the first sign signalling economic recession/revival. Therefore, with a view of assessing industry competitiveness of the Baltic States by RCA index, GDP is used to define the periods of economic recession (2008-2010) and revival (2011-2012) (see Fig. 1). Recession index calculated by Reklaite (2011) (Lithuanian case) showed that the Great Recession started in 2008, reached its peak during the period of 2009-2010, and began to retreat at the end of 2010 .

As it may be seen from Figure 1, since 2008 Estonian economy has been the least affected by the recession compared to Lithuania and Latvia. In the Estonian case, the recession slowed down due to the positive impact of export on GDP. Without the positive net export, GDP of the countries would have decreased even further. With reference to the data of Eurostat, in 2009 the net export of Lithuania amounted to 14.68 per cent of GDP, and to 11.90 per cent

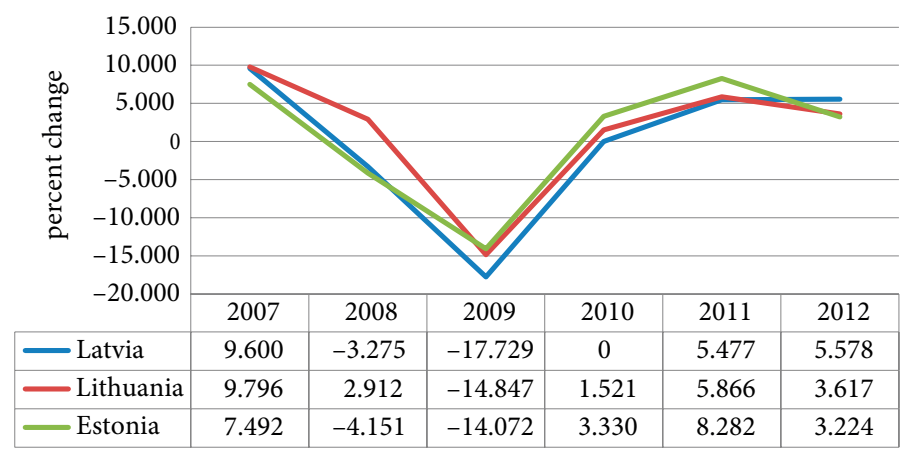

Fig. 1. Gross domestic product at the constant prices, the percent change in the Baltic States Source: drawn up by the authors with reference to the data of International Monetary Fund (2013) 
and 11.32 per cent in Latvia - and Estonia accordingly. Since the end of 2010 the GDP in Estonia and Lithuania has grown respectively by 3.33 and 1.521 per cent. In Latvia, positive changes of GDP dynamics can be observed only since the year 2010; the GDP amounted to 5.477 per cent.

With reference to the methodology of the empirical research introduced above, Table 2 summarizes the results of the assessment of the industry competitiveness of the Baltic States.

Table 2. The results of the assessment of the industry competitiveness of the Baltic States by RCA index during the period of 2007-2012

\begin{tabular}{|c|c|c|c|c|c|c|}
\hline SITC category/Country & 2007 & 2008 & 2009 & 2010 & 2011 & 2012 \\
\hline \multicolumn{7}{|c|}{ Food, drinks and tobacco } \\
\hline Estonia & 1.66 & 1.61 & 1.63 & 1.54 & 1.35 & 1.45 \\
\hline Latvia & 2.62 & 2.93 & 2.96 & 2.89 & 2.53 & 3.12 \\
\hline Lithuania & 3.19 & 2.86 & 3.16 & 2.96 & 2.68 & 2.82 \\
\hline \multicolumn{7}{|c|}{ Raw materials } \\
\hline Estonia & 4.08 & 3.91 & 3.26 & 3.50 & 2.82 & 2.82 \\
\hline Latvia & 7.71 & 5.98 & 5.48 & 5.96 & 5.35 & 4.92 \\
\hline Lithuania & 2.39 & 1.81 & 1.70 & 1.67 & 1.63 & 1.70 \\
\hline \multicolumn{7}{|c|}{ Mineral fuels, lubricants and related materials } \\
\hline Estonia & 2.33 & 1.88 & 3.10 & 2.66 & 2.61 & 2.00 \\
\hline Latvia & 0.69 & 0.55 & 0.95 & 0.89 & 1.21 & 1.03 \\
\hline Lithuania & 2.50 & 3.82 & 4.00 & 4.03 & 3.94 & 3.38 \\
\hline \multicolumn{7}{|c|}{ Chemicals and related products, n.e.s. } \\
\hline Estonia & 0.35 & 0.42 & 0.36 & 0.32 & 0.35 & 0.38 \\
\hline Latvia & 0.53 & 0.61 & 0.52 & 0.49 & 0.51 & 0.45 \\
\hline Lithuania & 0.85 & 0.91 & 0.77 & 0.76 & 0.84 & 0.81 \\
\hline \multicolumn{7}{|c|}{ Other manufactured goods } \\
\hline Estonia & 1.36 & 1.41 & 1.40 & 1.35 & 1.23 & 1.23 \\
\hline Latvia & 1.47 & 1.50 & 1.37 & 1.45 & 1.46 & 1.42 \\
\hline Lithuania & 1.13 & 0.97 & 1.08 & 1.06 & 1.00 & 1.01 \\
\hline \multicolumn{7}{|c|}{ Machinery and transport equipment } \\
\hline Estonia & 0.67 & 0.68 & 0.62 & 0.69 & 0.78 & 0.80 \\
\hline Latvia & 0.44 & 0.49 & 0.53 & 0.48 & 0.49 & 0.48 \\
\hline Lithuania & 0.53 & 0.44 & 0.41 & 0.43 & 0.43 & 0.42 \\
\hline \multicolumn{7}{|c|}{ Commodities and transactions not classified elsewhere in the SITC } \\
\hline Estonia & 0.12 & 0.08 & 0.13 & 0.19 & 0.34 & 0.42 \\
\hline Latvia & 0.03 & 0.02 & 0.08 & 0.08 & 0.09 & 0.20 \\
\hline Lithuania & 0.01 & 0.01 & 0.01 & 0.01 & 0.02 & 0.02 \\
\hline
\end{tabular}

* In the Table, calculated RCA values include the year 2007 with a view to comparison RCA values with the year 2012. 
Summarizing, the following conclusions can be made:

1) Lithuania, which had the highest competitive advantage in 2007 (RCA $=3.19)$ in the group of foods, drinks and tobacco, gave up the leader's positions to Latvia in 2012. In 2012, Latvia was the only from all three States to gain higher competitiveness in the industry of food, drinks and tobacco during the analysed period compared to the year $2007\left(\mathrm{RCA}_{2007}=2.62 ; \mathrm{RCA}_{2012}=3.12\right)$. Although the economic recession according to the rate of GDP is considered to have taken place during the period of 2008-2010, the competitiveness of food, drinks and tobacco industries in all three Baltic States reached the lowest point in 2011. Lithuania and Estonia were not able to achieve the pre-crisis level of competitiveness in the industries of food, drinks and tobacco.

2) In the group of raw materials, including such industries as wood and cork, textile, natural rubber, fur, oil, plant seeds and fruits, cellulose and waste paper, mineral raw materials, metal ores and scrap and others, the strongest positions during the analysed period were taken by Latvia: in 2007, RCA of this product group reached 7.71 in all the EU market. From 2008 to 2012 (with the exception of 2010), the competitiveness of raw materials in Latvia decreased, i.e. RCA values fell down from 5.98 to 4.92. In Estonia, it also decreased from 4.08 to 2.82 , and in Lithuania - from 2.39 to 1.70 . It indicates that the industry of raw materials in the Baltic States has not recovered after the recession because RCA values for 2012 are lower than during the pre-crisis period and even the period of economic recession.

3) In the group of mineral fuels, lubricants and related materials, including such industries as petroleum, petroleum products, coal, electric current, natural and manufactured gas, Lithuania remains the most competitive country among the Baltic States in the EU market during the period of 2007-2012. The highest competitiveness of this group of products was observed during the period of economic recession, i.e. in 2010 $\left(\right.$ RCA $\left.^{\text {Lithuania }}=4.03\right)$, and, although it tended to decline by 2012 , it was higher than in $2007\left(\mathrm{RCA}_{2007}=2.50 ; \mathrm{RCA}_{2012}=3.38\right)$. In Latvia, the industry of mineral fuels, lubricants and related materials had the lowest competitiveness compared to Estonia and Lithuania. Calculations revealed that Latvian RCA index for the group of mineral fuels, lubricants and related materials was higher than 1 only in 2011-2012, while in 2007-2010 it varied in the interval from 0.69 to 0.89 .

4) Competitiveness of chemicals was rather low in all three Baltic States in the EU market because the values of RCA during the analysed period did not reach 1; the dynamics of the index showed insignificant variation: $\mathrm{RCA}_{2007}^{\text {Lithuania }}=0.85 ; \mathrm{RCA}_{2012}^{\text {Lithuania }}=0.81$; $\mathrm{RCA}_{2007}^{\text {Latvia }}=0.53 ; \mathrm{RCA}_{2012}^{\text {Latvia }}=0.45 ; \mathrm{RCA}_{2007}^{\text {Estonia }}=0.35 ; \mathrm{RCA}_{2012}^{\text {Estonia }}=0.38$ ). During the period of economic recession, the competitiveness of the industry of chemicals had the tendency to decrease in all the Baltic States.

5) In the group of other manufactured goods (leather, rubber products, textile yearn, fabrics, furniture and their parts, paper, cardboard, iron and steel, footwear and others), the researched countries took similar competitive positions. Estonia took the strongest competitive positions in this group during the period of economic recession, i.e. its $\mathrm{RCA}_{2008}=1.41$ and $\mathrm{RCA}_{2009}=1.40$. Unfortunately, the country was not able to retain 
the same competitive advantage in the group of other manufactured goods, which decreased during the period of 2010-2012, and was lower compared to the year 2007 $\left(\mathrm{RCA}_{2012}=1.23 ; \mathrm{RCA}_{2007}=1.36\right)$. From this point of view, 2009 was the toughest year for Latvia, and 2008 - for Lithuania. However, just like Estonia, these two countries still have not been able to achieve the same competitive positions as in 2007.

6) The Baltic States do not take strong competitive positions in the industry of machinery and transport equipment in the EU market because calculated values of RCA for the researched period are lower than 1 . Commodities and transactions not classified elsewhere in the SITC are little considered further in the article due to the insignificant values of RCA.

In order to identify which industrial sector of the Baltic States has competitive advantage in the EU market and how this advantage changed during the periods of economic recession and revival, the industrial RCA indexes in the EU market, grouped by the classification of RCA values with reference to Hinloopen, van Marrewijk (2001), have been presented in Figure 2.

As it may be seen from Figure 2, only Latvia had strong comparative advantage (class $d$ ) and ensured strong competitive positions in the industry of raw materials $\left(\mathrm{RCA}_{2008}=5.97\right)$. During the years of business cycle revival, Latvia remained the strongest among all three Baltic States in the industry of raw materials, although its competitive advantage deceased $\left(\operatorname{RCA}_{2012}=4.9\right)$. Lithuania took medium comparative advantage (class $c$ ) in the industry of mineral fuel, lubricants and related materials in the EU market $\left(\mathrm{RCA}_{2008}=3.82 ; \mathrm{RCA}_{2012}=3,37\right)$, although, as in the case of Latvia, its competitive advantage in this industry in the stage of economic revival is lower than during the years of economic recession. Estonia had medium comparative advantage in the industry of raw materials, and, although it is lower than Latvia's, it gets into class c $\left(\mathrm{RCA}_{2008}=3.9\right.$; $\mathrm{RCA}_{2012}=2.8$ ). Both Lithuania and Latvia take similar competitive positions in the industry of food, i.e. $\mathrm{RCA}_{2008}^{\mathrm{Lithuania}}=2.86 ; \mathrm{RCA}_{2008}^{\text {Latvia }}=2.93 ; \mathrm{RCA}_{2012}^{\text {Lithuania }}=2.81 ; \mathrm{RCA}_{2012}^{\text {Latvia }}=3.12$.

Summarizing the calculations of RCA, it may be concluded that the consequences of the economic recession are still strongly felt in the period of economic revival, assessing the

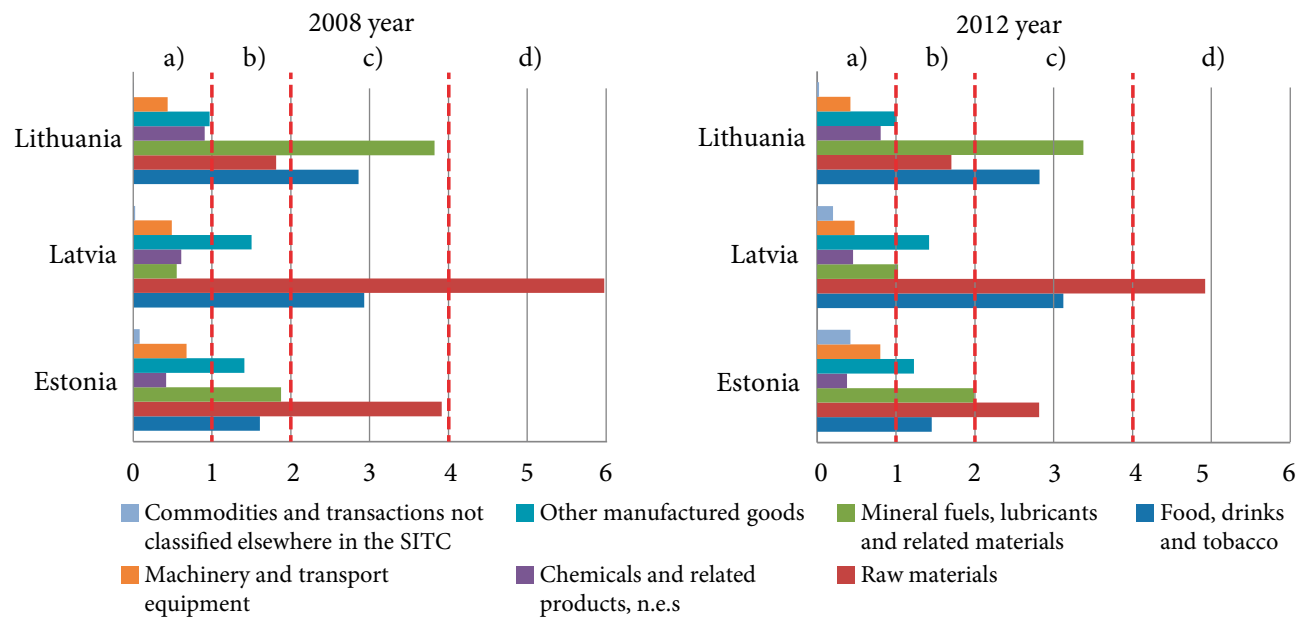

Fig. 2. Industrial RCA indexes of the Baltic States in the EU market in 2008 and 2012 Source: calculated by the authors with reference to the data of Eurostat (2013) 
industry competitiveness of the Baltic States. Such industries as raw materials, mineral fuel and lubricants, and related materials as well as other manufactured goods (textile, footwear, furniture and others) have not reached the level of competitive advantage of the year 2007. Although GDP in the Baltic States has been growing and it is clear that the economy has been recovering, the trend of industrial growth, assessing its competitiveness by export, has been lagging behind. The main reason for that is the insufficient level of investment in the companies operating in industrial sector. For example, Lithuanian share of the investment in machinery and equipment capital formation amounted to only 3.6 per cent of GDP, Latvian - 6.2 per cent of GDP, and Estonian - 8.2 per cent of GDP (Baltic Economic Outlook 2013).

In the second stage of the research, with a view of preventing the disadvantages of RCA index pointed above, SI index has been calculated. The results of SI index have been summarized in Table 3.

Table 3. The results of SI index for the Baltic States

\begin{tabular}{|c|c|c|c|c|c|}
\hline \multirow{2}{*}{ SITC06 } & \multicolumn{2}{|c|}{ SI value } & \multicolumn{2}{|c|}{ SI clasification } & \multirow{2}{*}{$\begin{array}{l}\text { Direction } \\
\text { of SI shift }\end{array}$} \\
\hline & 2010 & 2012 & 2010 & 2012 & \\
\hline \multicolumn{6}{|c|}{ Foods, drinks and tobacco } \\
\hline Estonia & 0.21 & 0.18 & Advantage & Advantage & - \\
\hline Latvia & 0.49 & 0.51 & Advantage & Advantage & + \\
\hline Lithuania & 0.50 & 0.48 & Advantage & Advantage & - \\
\hline \multicolumn{6}{|c|}{ Raw materials } \\
\hline Estonia & 0.56 & 0.48 & Advantage & Advantage & - \\
\hline Latvia & 0.71 & 0.66 & Advantage & Advantage & - \\
\hline Lithuania & 0.25 & 0.26 & Advantage & Advantage & + \\
\hline \multicolumn{6}{|c|}{ Mineral fuels, lubricants and related materials } \\
\hline Estonia & 0.45 & 0.33 & Advantage & Advantage & - \\
\hline Latvia & -0.06 & 0.01 & Disadvantage & Advantage & + \\
\hline Lithuania & 0.60 & 0.54 & Advantage & Advantage & - \\
\hline \multicolumn{6}{|c|}{ Chemicals and related products, n.e.s. } \\
\hline Estonia & -0.51 & -0.45 & Disadvantage & Disadvantage & - \\
\hline Latvia & -0.34 & -0.37 & Disadvantage & Disadvantage & + \\
\hline Lithuania & -0.14 & -0.11 & Disadvantage & Disadvantage & - \\
\hline \multicolumn{6}{|c|}{ Other manufactured goods } \\
\hline Estonia & 0.15 & 0.10 & Advantage & Advantage & - \\
\hline Latvia & 0.18 & 0.17 & Advantage & Advantage & - \\
\hline Lithuania & 0.03 & 0.004 & Advantage & Advantage & - \\
\hline \multicolumn{6}{|c|}{ Machinery and transport equipment } \\
\hline Estonia & -0.18 & -0.11 & Disadvantage & Disadvantage & + \\
\hline Latvia & -0.36 & -0.36 & Disadvantage & Disadvantage & 0 \\
\hline Lithuania & -0.40 & -0.41 & Disadvantage & Disadvantage & - \\
\hline
\end{tabular}

Note: Advantage means that the group of products has revealed comparative advantage (positive SI value) in the EU market, disadvantage - the group of products has not revealed comparative advantage in the EU market (negative SI value) (Kilduff, Chi 2007).

Source: drawn up by the authors with reference to the calculation data. 
With the goal of comparing the situation of industrial competitive advantage of the Baltic States during different stages of business cycle, the year of 2010 (the stage of recession) and the year of 2012 (the stage of revival) have been chosen. Summarising the results of SI index, it may be concluded that:

1) In the stage of economic recession, the Baltic States had higher competitive advantage in such industries as food, drinks and tobacco, raw materials and mineral fuel, lubricants and related materials (except Latvia) compared to the stage of economic revival.

2) The Baltic States have not demonstrated the competitive advantage in the EU market in such industries as chemicals, machinery and transport equipment.

3) In the industry of other manufactured goods, the Baltic States had very weak competitive positions in the EU market.

Comparing the results of SI and RCA indexes, it may be noticed that the results are very similar and show the same tendencies of the change in industry competitiveness. Therefore, the authors of the article are of the opinion that only one of these indexes can be used for further research, i.e. there is no need to calculate both indexes.

In the third stage of the research, export competitiveness index (XCI) is calculated for the competitive industries selected by RCA index. XCI reveals whether an industry has increasing competitive advantage comparing the period under review (2012) with the previous period (2011) (Amir 2000) see Table 4.

The results of XCI index show that the researched countries, especially during the period of economic recession, aimed to keep rather than decrease the volumes of export, which was considered to help retain their industry competitiveness, i.e.:

- in the industry offood, drinks and tobacco, all three Baltic States had growing competitive positions in 2009 compared to 2008 as well as comparing 2012 to 2011;

- in the industry of raw materials, all three Baltic States had increasing competitive positions during the period of economic recession (2009/2010), but only Lithuania was able to retain them up to 2012 ;

- in the industry of mineral fuels, lubricants and related material, Latvia retained its potential during the period of 2008-2011, Estonia - during the period of economic recession and at the end of it, Lithuania - at the end of the recession and at the beginning of revival, i.e. the dynamics of XCI index for the researched countries was not stable, so further insights to the trends of growth/fall of the competitiveness of this industry are difficult to make;

- comparing the year 2008 with 2007 and the year 2009 with 2008, it may be noticed that in the industry of chemicals and related products, n.e.s., all three countries showed the tendency of industrial export until the period of economic recession. XCI values for the period of economic recession and the period under review demonstrate that Latvian and Lithuanian industries of chemicals do not show any signs of revival, i.e. the values of the index are lower than 1. Estonian indexes are better (the values are higher than 1), revealing that Estonian industry of chemicals shows the signs of recovery in the stage of economic revival; 
Table 4. XCI index values calculated for the different groups of exported goods in the Baltic States

\begin{tabular}{|c|c|c|c|c|c|}
\hline Country/SITC06 & $2007 / 2008$ & $2008 / 2009$ & $2009 / 2010$ & $2010 / 2011$ & $2011 / 2012$ \\
\hline \multicolumn{6}{|c|}{ Foods, drinks and tobacco } \\
\hline Estonia & 1.01 & 1.12 & 0.93 & 0.89 & 1.12 \\
\hline Latvia & 1.16 & 1.11 & 0.96 & 0.89 & 1.28 \\
\hline Lithuania & 0.93 & 1.21 & 0.92 & 0.92 & 1.09 \\
\hline \multicolumn{6}{|c|}{ Raw materials } \\
\hline Estonia & 0.96 & 0.87 & 1.17 & 0.84 & 0.98 \\
\hline Latvia & 0.78 & 0.95 & 1.19 & 0.93 & 0.90 \\
\hline Lithuania & 0.76 & 0.97 & 1.07 & 1.02 & 1.02 \\
\hline \multicolumn{6}{|c|}{ Mineral fuels, lubricants and related materials } \\
\hline Estonia & 0.97 & 1.37 & 0.94 & 1.09 & 0.87 \\
\hline Latvia & 0.96 & 1.43 & 1.02 & 1.51 & 0.96 \\
\hline Lithuania & 1.84 & 0.87 & 1.10 & 1.09 & 0.97 \\
\hline \multicolumn{6}{|c|}{ Chemicals and related products, n.e.s. } \\
\hline Estonia & 1.14 & 1.03 & 0.86 & 1.03 & 1.09 \\
\hline Latvia & 1.09 & 1.01 & 0.92 & 0.97 & 0.90 \\
\hline Lithuania & 1.02 & 1.01 & 0.95 & 1.05 & 0.96 \\
\hline \multicolumn{6}{|c|}{ Other manufactured goods } \\
\hline Estonia & 1.00 & 0.97 & 0.93 & 0.90 & 1.00 \\
\hline Latvia & 0.99 & 0.90 & 1.03 & 1.00 & 0.97 \\
\hline Lithuania & 0.83 & 1.09 & 0.95 & 0.94 & 1.00 \\
\hline \multicolumn{6}{|c|}{ Machinery and transport equipment } \\
\hline Estonia & 1.00 & 0.88 & 1.12 & 1.11 & 1.04 \\
\hline Latvia & 1.10 & 1.05 & 0.90 & 1.02 & 0.97 \\
\hline Lithuania & 0.82 & 0.90 & 1.05 & 1.00 & 0.99 \\
\hline \multicolumn{6}{|c|}{ Commodities and transactions not classified elsewhere in the SITC } \\
\hline Estonia & 1.04 & 1.48 & 1.68 & 2.10 & 0.89 \\
\hline Latvia & 1.10 & 3.50 & 1.15 & 1.27 & 1.64 \\
\hline Lithuania & 1.30 & 1.09 & 1.13 & 1.94 & 0.93 \\
\hline
\end{tabular}

Source: drawn up by the authors with reference to the calculations.

- Estonia and Lithuania had increasing competitive advantage in the industry of other manufactured goods during the period of economic revival, while Latvian XCI value (0.97) revealed the decreasing level of competitiveness. Comparing with the period of economic recession, XCI index for Latvian industry of other manufactured goods was equal to or higher than 1, i.e. during the period of economic recession, the country exported more goods than during the period of economic revival; 
- the results of calculations for the industry of machinery and transport equipment in Estonia show positive but decreasing trends of growth from 2009 to 2012. For other countries, the values of XCI have distributed unevenly, so it is difficult to estimate the projection of export growth/decline;

- the results of the calculations for the industry of commodities and transactions not classified elsewhere in the SITC group were rather interesting, revealing that all three countries should have the competitive advantage. Low indexes were captured only for Lithuania and Latvia in 2011/2012.

\section{Conclusions}

1. Until 2004, all three Baltic States remained competitive in the industries producing goods from raw materials and exporting them to foreign markets. Since the entry to the EU, the countries strengthened their positions in the industries of food, drinks and tobacco, mineral fuel, raw materials and other manufactured goods. Stronger competitive advantage in these industries is caused by the increase of food prices in global markets and the Baltic region as well as greater purchasing power of the CIS residents. The research revealed that the level of industry competitiveness of the Baltic States during the period of economic recession (2008-2010) has hardly been analysed.

2. Export, especially during the period of economic recession, became one of the main business strategies for companies due to shrinking internal markets. Because of this reason, RCA, SI and XCI indexes were chosen for the assessment of industry competitiveness, analysing the proportional part of the particular industry in export. The results of the empirical research revealed that RCA and SI indexes show similar results, which means that the problem of asymmetry has been prevented while assessing the industry competitiveness of the Baltic States.

3. During the stages of economic recession and economic revival the Baltic States revealed comparative advantage in the industries of food, drinks and tobacco, raw materials, mineral fuel, lubricants and related materials. The values of RCA index revealed that economic recession had negative impact on such industries as raw materials, mineral fuel and lubricants and related materials, and other manufactured goods, including textile, furniture, footwear and others. In 2012, these industries failed to reach the level of competitive advantage gained in 2007.

4. The values of XCI index revealed (comparing the year 2012 with 2011) the growing competitive advantage of the Baltic States in the industries of food, drinks and tobacco. Lithuania has ensured its potential in the industries of raw materials and other manufactured goods, Estonia - in the industries of chemicals, machinery and transport equipment and other manufactured goods, Latvia - in the industries of commodities and transactions not classified elsewhere in the SITC. Insufficient investment in the companies operating in industrial sector has been pointed out as one of the obstacles to increase the competitiveness of the industry in respect of export. 


\section{References}

Amir, M. 2000. Export specialization and competitiveness of the Malaysian manufacturing: trends, challenges and prospects, Conference on International Trade Education and Research, 26-27 October 2000, Melbourne.

Athukorala, P. 2006. Post-crisis export performance: the Indonesian experience in regional perspective, Bulletin of Indonesian Economic Studies 42(2): 177-211. http://dx.doi.org/10.1080/00074910600873658

Bair, J.; Gereffi, G. 2001. Local clusters in global chains: the causes and consequences of export dynamism in Torreon's blue jeans industry, World Development 29(11): 1885-1903. http://dx.doi.org/10.1016/S0305-750X(01)00075-4

Balasubramanyam, V. N.; Wei, Y. 2005. Textiles and clothing exports from India and China: a comparative analysis, Journal of Chinese Economic and Business Studies 3(1): 23-27. http://dx.doi.org/10.1080/14765280500040427

Baltic Economic Outlook [online]. 2013 [cited 18 October 2013]. Available from Internet: https://www. dnb.lt/sites/default/files/research/dnb_baltic_economic_outlook_2013_spring.pdf

Beņkovskis, K. 2012. Competitiveness of Latvia's exporters, Baltic Journal of Economics 12(2): 17-45. http://dx.doi.org/10.1080/1406099X.2012.10840516

Bernatonyte, D.; Normantiene, A. 2009. Estimation of trade specialization: the case of Baltic states, Inzinerine Ekonomika - Engineering Economics (2): 7-17.

Buracas, A.; Zvirblis, A.; Joksiene, I. 2012. Measurement of entrepreneurship macro surrounding advantages: country's economic competitiveness approach, Inzinerine Ekonomika - Engineering Economics 23(1): 5-13.

Dudzevičiūtė, D.; Mačiulis, A.; Tvaronavičienè, M. 2014. Structural changes of economies: Lithuania in the global context, Technological and Economic Development of Economy 20(2): 353-370. http://dx.doi.org/10.3846/20294913.2014.915597

Eurostat [online]. 2013 [cited 19 August 2013]. Available from Internet: http://epp.eurostat.ec.europa. eu/portal/page/portal/eurostat/home/

Fadejeva, L.; Melihovs, A. 2008. The Baltic states and Europe: common factors of economic activity, Baltic Journal of Economics 8(1): 75-96. http://dx.doi.org/10.1080/1406099X.2008.10840446

Fertö, I. 2007. The dynamics of trade in Central and Eastern European Countries, Managing Global Transitions 5(1): 5-23.

Fischer, Ch.; Schornberg, S. 2007. The competitiveness situation of EU meat processing and beverage manufacturing sectors, Food Economics - Acta Agricult Scand C 4: 148-158.

Fortunas, S.; Diniz, F.; Katsioloudes, M. 2007. The competitiveness of the Portuguese wine sector, Food Economics - Acta Agricult Scand C 4: 120-128.

Global Competitiveness Index [online]. 2014 [cited 14 September 2014]. Available from Internet: http://www.weforum.org/issues/competitiveness-0/gci2012-data-platform/

Haar, L. N. 2010. Industrial restructuring in Romania from a bilateral trade perspective: manufacturing exports to the EU from 1995 to 2006, Europe - Asia Studies 62(5): 779-805. http://dx.doi.org/10.1080/09668136.2010.481386

Hinloopen, J.; van Marrewijk, C. 2001. On the empirical distribution of the Balassa index, Weltwirtschaftliches Archiv 137: 1-35. http://dx.doi.org/10.1007/BF02707598

Hinloopen, J.; Marrewijk, Ch. 2008. Empirical evidence of the Hillman condition for revealed comparative advantage: 10 stylized facts, Applied Economics 40: 2313-2328. http://dx.doi.org/10.1080/00036840600949488

Iammarino, S.; McCann, P. 2006. The structure and evolution of industrial clusters: transactions, technology and knowledge spillovers, Research Policy 35: 1018-1036.

http://dx.doi.org/10.1016/j.respol.2006.05.004 
International Monetary Fund [online]. 2013 [cited 7 September 2013]. Available from Internet: http://www.imf.org/external/data.htm.

Kaitila, V. 1999. Trade and revealed comparative advantage: Hungary, the Czech Republic, and the European Union, BOFIT Discussion Paper No. 8/1999.

Kaitila, V. 2001. Accession countries comparative advantage in the internal market: a trade and factor analysis, BOFIT Discussion Paper No. 3/2001.

Kilduff, P.; Chi, T. 2007. Analysis of comparative advantage in the textile complex: a study of Eastern European and former Soviet Union nations, Journal of Fashion Marketing and Management 11(1): 82-106. http://dx.doi.org/10.1108/13612020710734427

Kuldilok, K. S.; Dawson, P. J.; Lingard, J. 2013. The export competitiveness of the tuna industry in Thailand, British Food Journal 115(3): 328-341. http://dx.doi.org/10.1108/00070701311314174

Lederman, D.; Olarrega, M.; Rubiano, E. 2008. Trade specialization in Latin America: the impact of China and India, Review of World Economics 144(2): 248-271. http://dx.doi.org/10.1007/s10290-008-0146-Z

Mahmood, A. 2010. Shifting export specialization and the competitiveness of the Malaysian manufacturing: trends and analysis, The International Trade Journal 15(2): 187-219. http://dx.doi.org/10.1080/08853900117637

Malakauskaite, A.; Navickas, V. 2011. Contribution of clusters to the competitiveness of companies: revelation and evaluation, Inzinerine ekonomika - Engineering Economics 22(1): 50-57.

Meiliene, E.; Snieska, V. 2010. Lietuvos pramonès konkurencingumo veiksniai eksporto politikos nuostatose, Viešoji politika ir administravimas 31: 119-132.

Michalek, J.; Odehnal, J.; Sedlacik, M. 2012. A competitiveness evaluation of the Ukrainian regions, Inzinerine ekonomika - Engineering Economics 23(4): 406-413.

Misztal, P. 2009. International competitiveness of the Baltic States in the transformation period: Lithuania, Latvia and Estonia, Transformations in Business \& Economics 8(3): 21-35.

Nilsson, F. O. L.; Lindberg, E.; Surry, Y. 2007. Are the Mediterranean countries competitive in fresh fruit and vegetable exports?, Food Economics - Acta Agricult Scand C 4: 203-216.

Newlands, D. 2003. Competition and cooperation in industrial clusters: the implications for public policy, European Planning Studies 11(5): 521-532. http://dx.doi.org/10.1080/09654310303649

Oelgemöller, J. 2013. Revealed comparative advantages in Greece, Ireland, Portugal and Spain, Intereconomics 4: 243-253. http://dx.doi.org/10.1007/s10272-013-0466-7

Reklaite, A. 2011. Coincident, leading and recession indexes for the Lithuanian economy, Baltic Journal of Economics 11(1): 91-107. http://dx.doi.org/10.1080/1406099X.2011.10840492

Rasiah, R.; Myint, M. M. 2013. Ownership, technological capabilities and exports of garment firms in Myanmar, Technological and Economic Development of Economy 19(sup1): S22-S42. http://dx.doi.org/10.3846/20294913.2013.869513

Razavi, S. H.; Hashemi, S. S.; Zavadskas, E. K. 2012. Prioritization of export promotion programs by Fuzzy linear assignment method, Inzinerine ekonomika - Engineering Economics 23(5): 462-470.

Saboniene, A. 2009. Lithuanian export competitiveness: comparison with other Baltic States, Inzinerine Ekonomika - Engineering Economics (2): 49-57.

Saboniene, A.; Pukeliene, V. 2004. Produkcijos konkurencingumo rodiklių svarba pramonès i̇monių strategijos ir šalies pramonès politikos formavimui Europos Sąjungos bendrojoje rinkoje, Organizaciju vadyba: sisteminiai tyrimai 2 .

Sanidas, E.; Shin, Y. 2010. Comparison of revealed comparative advantage indices with application to trade tendencies of East Asian Countries [online], [cited 10 January 2014]. Available from Internet:

http://www.akes.or.kr/eng/papers(2010)/24.full.pdf 
Shafaei, R. 2009. An analytical approach to assessing the competitiveness in the textile industry, Journal of Fashion Marketing and Management 13(1): 20-36. http://dx.doi.org/10.1108/13612020910939851

Taylor, T. G. 2009. Export diversification in Latin America and the Caribbean, The International Trade Journal 17(2): 101-128. http://dx.doi.org/10.1080/08853900390200157

Vanitha, S. M.; Kumari, G.; Singh, R. 2013. Export competitiveness of fresh vegetables in India, International Journal of Vegetable Science 20(3): 227-234. http://dx.doi.org/10.1080/19315260.2013.789812

Vasta, M. 2010. Italian export capacity in the long-term perspective (1861-2009): a tortuous path to stay in place, Journal of Modern Italian Studies 15(1): 133-156. http://dx.doi.org/10.1080/13545710903465614

Vogiatzoglou, K. 2012. Intra and extra-EU intra-industry trade in Greece: trade, determinants, and structural adjustment, Journal of Economics and Social Research 9(1): 19-54.

Zaghini, A. 2005. Evolution of trade patterns in the new EU member states, Economics of Transitions 13(4): 629-658. http://dx.doi.org/10.1111/j.0967-0750.2005.00235.x

Rita REMEIKIENE. First degree in business management, Kaunas University f Technology (2001). Master of Marketing (2003). Doctor in economics (2012). Research visits to Granada University (Spain, 2014) and BA School of Business and Finance (Latvia, 2013). Project manager in International Study Project "Nord Plus Horizontals" (from 2014, August). Author of about 35 scientific articles. Research interests: self-employment, entrepreneurship, outsourcing and shadow economy.

Grazina STARTIENE. Doctor's degree in economics (St. Petersburg State University, 1987). From 2006 until now Professor. Research visits to Riga Technical University (Latvia, 2008), Brno University of Technology (Czech Republic, 2009), Granada University (Spain, 2010) and Rey Juan Carlos University (Spain, 2012). Project manager in the 1st Study Degree Program Quality and Internationalization Improvement in Kaunas University of Technology Faculty of Economics and Management and Alytus Colleague Management Faculty (2010-2012); German Academic Exchange Service (DAAD) / Expert for Research Grants and Study Scholarships (from 2004 till now). Author of about 75 scientific articles, scientific monograph and textbook. Research interests: international payments, international economics, smart economics.

Daiva DUMCIUVIENE. Doctor's degree in economics (Kaunas University of Technology, 1999), professor at the School of Economics and Business, Kaunas University of Technology. Participation in international INTEREG research project "Corporate social and environmental responsibility in terms of public policy", 8 projects within LLP programme. Author of more than thirty scientific articles, scientific monograph and textbook. Lecturer in foreign universities: Wismar University, Germany (2014); Coimbra Business School, Portugal (2013); University of Rome "La Sapienza", Italy (2005); Padova University, Italy (2003); Jönköping Internatonal Business School, Sweden (2000, 2002, 2004). Expert-evaluator of FP7 projects at European Commission, DG Research; evaluator of research proposals in social sciences at National Centre for Research and Development, Warsaw, Poland; at National Centre of Science and Technology Evaluation, Astana, Kazakhstan; at Executive Agency for Higher Education, Research, Development and Innovation Funding, Romania. Research interests: international integration, competitiveness and cohesion, economic growth. 